\title{
Sequential Prodrug Strategy To Target and Eliminate ACPA- Selective Autoreactive B Cells
}

\author{
Lianne P. W. M. Lelieveldt, ${ }^{\dagger}$ Hendy Kristyanto, ${ }^{\dagger}$ Ger J. M. Pruijn, ${ }^{\dagger}$ Hans Ulrich Scherer, ${ }^{\ddagger}$
} René E. M. Toes, ${ }^{+}$and Kimberly M. Bonger* ${ }^{*}+0$

${ }^{\dagger}$ Department of Biomolecular Chemistry, Institute for Molecules and Materials, Radboud University Nijmegen 6525 AJ, The Netherlands

${ }^{\ddagger}$ Department of Rheumatology, Leiden University Medical Center, Leiden, The Netherlands

\section{Supporting Information}

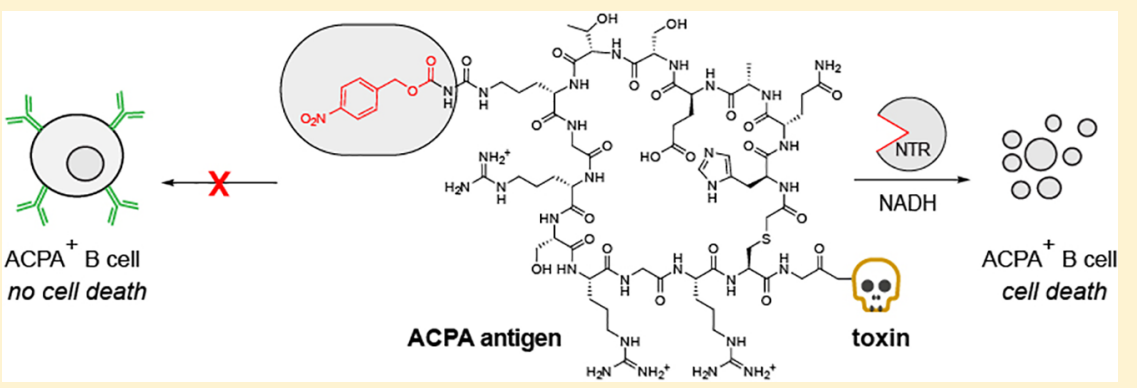

ABSTRACT: Autoreactive B cells are thought to play a pivotal role in many autoimmune diseases. Rheumatoid arthritis (RA) is an autoimmune disease affecting $\sim 1 \%$ of the Western population and is hallmarked by the presence of anticitrullinated proteins antibodies (ACPA) produced by autoreactive B cells. We intend to develop a method to target and selectively eliminate these autoreactive B cells using a sequential antigen prodrug targeting strategy. As ACPA-expressing B cells are thought to play essential roles in RA-disease pathogenesis, we used this B cell response as a prototype to analyze the feasibility to generate a construct consisting of a biologically silenced, that is, blocked, antigen connected to a cytotoxic prodrug. Blocking of the antigen is considered relevant as it is anticipated that circulating autoantibodies will otherwise clear the antigen-prodrug before it can reach the target cell. The antigen-prodrug can only bind to the autoantigen-specific B cell receptor (BCR) upon enzymatic removal of the blocking group in close proximity of the B cell surface. BCR binding ultimately induces antigenspecific cytotoxicity after internalization of the antigen. We have synthesized a cyclic citrullinated peptide (CCP) antigen suitable for BCR binding and demonstrated that binding by ACPA was impaired upon introduction of a carboxy-p-nitrobenzyl $(\mathrm{CNBz})$ blocking group at the side chain of the citrulline residue. Enzymatic removal of the $\mathrm{CNBz}$ moiety by nitroreductase fully restored citrulline-specific recognition by both ACPA and ACPA-expressing B cells and showed targeted cell death of CCP-recognizing B cells only. These results mark an important step toward antigen-specific B cell targeting in general and more specifically in RA, as successful blocking and activation of citrullinated antigens forms the basis for subsequent use of such construct as a prodrug in the context of autoimmune diseases.

KEYWORDS: Rheumatoid arthritis, peptidylcitrulline, anticitrullinated protein antibodies, B cell targeting, antigen silencing and activation

\section{INTRODUCTION}

Many autoimmune diseases are characterized by the presence of antibodies that are directed toward self-antigens. ${ }^{1}$ The importance of autoreactive B cells in autoimmunity is well recognized; however, the exact mechanisms of their involvement have not been fully established. Rheumatoid arthritis (RA) is an inflammatory autoimmune disease that is characterized by chronic synovitis and erosive destruction of articular cartilage and bone. RA affects $0.5-1 \%$ of adults in the developed world. ${ }^{2}$ Of these patients, $70-80 \%$ harbor anticitrullinated protein antibodies (ACPA). ${ }^{3}$

Protein citrullination, the process where a peptidylarginine is enzymatically converted into a peptidylcitrulline by peptidy- larginine deiminase (PAD), is a post-translational modification commonly observed in inflammation. ${ }^{4}$ Antibodies directed toward citrullinated proteins can be detected several years before the onset of RA, associate with severity of the disease, and are therefore an interesting marker to predict the development of RA. ${ }^{5}$ Cyclic citrullinated peptides (CCPs) are often used as a test substrate for the detection of ACPA. ${ }^{6}$

Received: July 13, 2018

Revised: September 18, 2018

Accepted: October 5, 2018

Published: October 5, 2018 


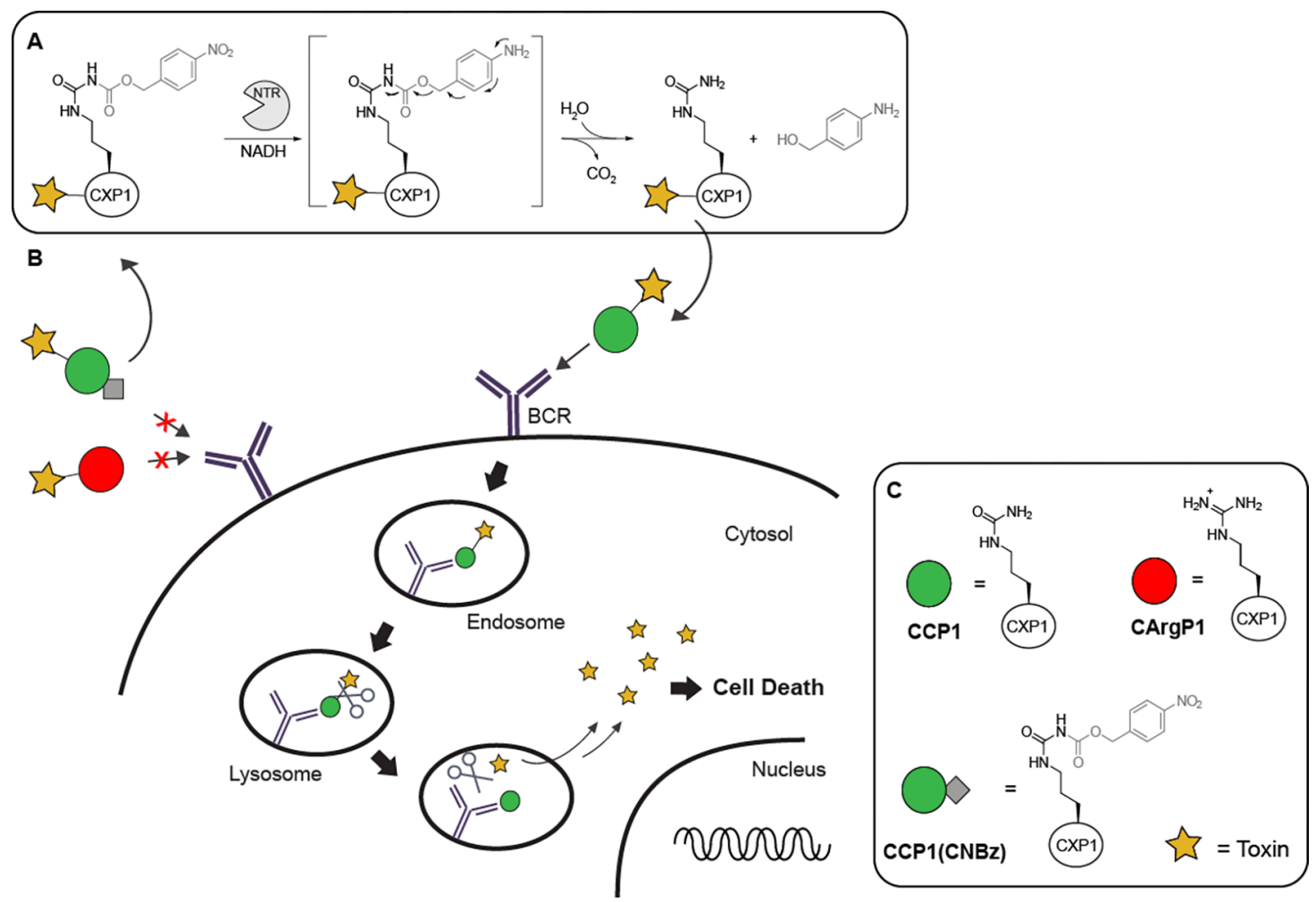

Figure 1. Schematic representation of the sequential prodrug strategy. (A) Antigen activation mechanism. NTR reduction of the aromatic nitro group to the (hydroxyl)amine results in 1,6-elimination of the $\mathrm{CNBz}$ blocking group; (B) CArgP and $\mathrm{CCP}(\mathrm{CNBz})$ are not recognized by the $\mathrm{BCR}$. After reduction by NTR, the activated CCP-toxin binds the BCR inducing BCR-mediated internalization and initiation of cell death. (C) Schematic representation of the CXP peptides used. CCP contains citrulline, CArgP contains arginine, and $\mathrm{CCP}(\mathrm{CNBz})$ contains the carboxynitrobenzyl blocking moiety on the citrulline.

Depletion of CD20-expressing B cells (e.g., using Rituximab) is effective in treating RA. ${ }^{7}$ The therapeutic effect is greater in ACPA-positive RA patients than in the ACPAnegative counterpart. $^{8}$ These observations suggest that autoreactive, ACPA-expressing B cells may play central roles in driving and maintaining the inflammatory processes in RA. As CD20-expression by $\mathrm{B}$ cells is not restricted to the autoreactive B cell compartment, depletion of the entire CD20-positive population by rituximab leads to immune deficiency against infectious agents. ${ }^{9}$ Therefore, a strategy to specifically deplete autoreactive B cells is of great interest. For example, the use of an autoantigen-toxin conjugate that selectively targets the BCR can be beneficial.

So far, researchers have used autoantigens as part of specific targeting strategies for autoreactive B cells. For example, Reiners and co-workers showed that by using proteinase 3 , an autoantigen in Wegener's granulomatosis, conjugated to an angiogenin toxin, proteinase 3-specific B cell hybridomas could be selectively targeted. ${ }^{10}$ Similar approaches using alternative toxins have also been described for the selective targeting of $\mathrm{B}$ cells involved in multiple sclerosis ${ }^{11,12}$ or B cells producing antibodies against a tetanus toxoid fragment. ${ }^{13}$ However, since specific B cells can differentiate into plasma cells excreting the same immunoglobulin, antigen-conjugates might be cleared by these free circulating autoantibodies. To improve B cell binding in these strategies, we suggest that reduction of autoantibody-mediated clearance of the autoantigen could be beneficial.

Here, we aimed to develop a sequential antigen-prodrug targeting strategy using the archetypic RA-specific autoimmune response as example, where a specific citrullinated peptide (cyclic citrullinated peptide, CCP) $)^{14-16}$ was conjugated to a cytotoxic entity (Figure 1). As CCP is able to bind to ACPAexpressing B cells and to soluble, free-circulating ACPA, we introduced a blocking group to circumvent undesired antigen binding to soluble ACPA upon administration. We envisioned that the exposure of the citrullinated epitope of the antigen can be locally restored to ensure high concentrations of the antigen-drug conjugate in close proximity of ACPA-expressing $\mathrm{B}$ cells (Figure 1). Antigen binding via the specific B cell receptor followed by internalization of the toxin conjugate should subsequently result in selective ACPA-positive B cell death.

We based our approach on the concept of an antibodydirected enzyme prodrug therapy (ADEPT) as our ultimate goal for the deprotection of CCP. This strategy has been explored extensively for local activation of cytotoxic prodrugs for tumor treatment. ${ }^{17}$ In an ADEPT strategy, an enzyme is conjugated to a targeting antibody after which a nontoxic prodrug is administered. The prodrug is then locally activated by the enzyme, releasing the toxin specifically at the directed site. Several enzymes have been explored for this strategy including alkaline phosphatase, ${ }^{18}$ beta-lactamase, ${ }^{19}$ and carboxy-peptidase G2. ${ }^{20}$

In our studies, we focused on using nitroreductase (NTR), which reduces an aromatic nitro group into an amine (or hydroxylamine). ${ }^{21}$ This enzyme has been explored before in ADEPT strategies, where a potent cytotoxic drug was liberated in vivo upon reduction of the aromatic nitro group. ${ }^{22,23}$ In this and other studies, a nitrobenzyl alcohol protecting group was 
used as self-immolative linker upon reduction. ${ }^{24-26} \mathrm{We}$ therefore envisioned that a carboxy- $p$-nitrobenzyl (CNBz) would serve as a good blocking group for citrulline and that reduction by NTR would initiate 1,6-elimination and $\mathrm{CO}_{2}$ release, resulting in a free ureido group at the citrulline side chain (Figure 1A). In our study, we used NTR as a proof of concept for selective deprotection of CCP as a prototype autoantigen, acting on the assumption that this concept can in the future be implemented into an ADEPT strategy.

\section{MATERIALS AND METHODS}

Materials. General information on material and methods is provided in the Supporting Information.<smiles>NC(CCCNC(=O)NC(=O)OCc1ccc([N+](=O)[O-])cc1)C(=O)O</smiles>

Synthesis. Synthetic procedure for 14-(9H-fluoren-9-yl)-1(4-nitrophenyl)-3,5,12-trioxo-2,13-dioxa-4,6,11-triazatetradecane-10-carboxylic acid (1). Fmoc-Cit-OH (2.00 g, 5.03 mmol, 1 equiv) was dissolved in THF $(115 \mathrm{~mL})$ and heated to $40{ }^{\circ} \mathrm{C}$. 4-Nitrobenzylchloroformate (1.63 g, $7.55 \mathrm{mmol}, 1.5$ equiv) was dissolved in THF $(5 \mathrm{~mL})$ and added to Fmoc-Cit$\mathrm{OH}$. The reaction mixture was stirred overnight. The mixture was concentrated in vacuo and the mixture was purified over silica $\left(2.5-5 \% \mathrm{MeOH}\right.$ in $\left.\mathrm{CH}_{2} \mathrm{Cl}_{2}\right)$, yielding a yellow solid product (1) (948 mg, 77\% after regaining starting material). Rf $=0.49\left(5 \% \mathrm{MeOH}\right.$ in EtOAc). ${ }^{1} \mathrm{H}$ NMR $(500 \mathrm{MHz}$, Chloroform-d) $\delta 9.08(\mathrm{~s}, 1 \mathrm{H}), 8.15(\mathrm{~d}, J=8.3 \mathrm{~Hz}, 2 \mathrm{H})$, $7.93(\mathrm{~s}, 1 \mathrm{H}), 7.73(\mathrm{~d}, J=7.5 \mathrm{~Hz}, 2 \mathrm{H}), 7.63-7.52(\mathrm{~m}, 2 \mathrm{H})$, 7.43 (d, $J=8.1 \mathrm{~Hz}, 2 \mathrm{H}), 7.37(\mathrm{t}, J=7.3 \mathrm{~Hz}, 2 \mathrm{H}), 7.31-7.26$ $(\mathrm{m}, 2 \mathrm{H}), 5.58(\mathrm{~d}, J=6.2 \mathrm{~Hz}, 1 \mathrm{H}), 5.17(\mathrm{~s}, 2 \mathrm{H}), 4.43(\mathrm{~s}, 1 \mathrm{H})$, 4.39 (d, $J=6.6 \mathrm{~Hz}, 2 \mathrm{H}), 4.19(\mathrm{t}, J=6.6 \mathrm{~Hz}, 1 \mathrm{H}), 3.46-3.11$ $(\mathrm{m}, 2 \mathrm{H}), 1.98-1.69(\mathrm{~m}, 2 \mathrm{H}), 1.66-1.55(\mathrm{~m}, 2 \mathrm{H}) .{ }^{13} \mathrm{C}$ NMR (126 MHz, Chloroform-d) $\delta 176.01,156.18,154.74,153.97$, $147.97,143.75,142.18,141.42$, 128.40, 127.87, 127.19, 125.19, 123.99, 120.14, 67.07, 66.30, 53.49, 47.32, 39.45, 29.64, 25.51. HRMS (ESI+) $m / z$ calcd for $\mathrm{C}_{29} \mathrm{H}_{28} \mathrm{~N}_{4} \mathrm{NaO}_{9}{ }^{+}[\mathrm{M}+\mathrm{Na}]^{+}$ 599.17485 , found 599.17540 .

General Peptide Synthesis. The first amino acid, FmocLys $(\mathrm{Mtt})-\mathrm{OH}$, (2 equiv) was added to the Wang resin with DIPCDI ( 2 equiv), HOBt ( 4 equiv), and DMAP ( 2 equiv) in DMF. The mixture was shaken for $16 \mathrm{~h}$ at room temperature. After washing, the Mtt group was cleaved off using 2\% TFA in DCM repeatable for 2 min. After washing with DCM and DMF, biotin was coupled using DIPCDI (3.3 equiv) and HOBt (3.6 equiv). Upon completion, the resin was flushed three times with DMF and piperidine was then added for 30 min to cleave off the Fmoc protecting group. The resin was subsequently flushed three times with DMF. A mixture of 3 equiv Fmoc-AA-OH, 3.6 equiv $\mathrm{HOBt}$, and 3.3 equiv DIPCDI was added to the resin to bind the subsequent amino acid. This reaction was incubated for $30 \mathrm{~min}$ at room temperature. After coupling of the next amino acid, the remaining free amines are capped with acetic anhydride $(1 \mathrm{~mL})$ and pyridine $(1 \mathrm{~mL})$ in DMF $(12 \mathrm{~mL})$. After washing three times with DMF, piperidine was added again and the cycles continued. After the last amino acid, chloroacetic anhydride ( 5 equiv) and DIPEA ( 5 equiv) were added in DMF and shaken for $45 \mathrm{~min}$.
Finally, a mixture of $92.5 \%$ TFA, $2.5 \% \mathrm{H} 2 \mathrm{O}, 2.5 \%$ EDT, and $2.5 \%$ TIPS was made. This mixture was added to the resin and incubated for $3 \mathrm{~h}$ at room temperature to cleave off the peptide from the resin and to deprotect the amino acid residues. The peptide was precipitated in diethyl ether, filtered, and dried. Kaiser tests were performed to follow the coupling reactions.

General Peptide Cyclization. The crude peptides were dissolved in a $50 \mathrm{mM} \mathrm{NH}_{4} \mathrm{HCO}_{3}$ buffer $\mathrm{pH}$ 8.4: $\mathrm{MeCN}$ 1:1, at a concentration of $2 \mathrm{mg} / \mathrm{mL}$ and stirred for $24 \mathrm{~h}$. MeCN was evaporated, and the remaining $\mathrm{H}_{2} \mathrm{O}$ was lyophilized. The peptides were purified using preparative reversed-phase HPLC and analyzed using analytical HPLC.

CArgP1 (2). CArgP1 was synthesized following the procedures described in the general peptide synthesis. Next, this peptide was cyclized and purified as described in the general cyclization method. HPLC: rt. $12.731 \mathrm{~min}$. LC-MS (ESI+) $m / z$ calcd for $\mathrm{C}_{100} \mathrm{H}_{172} \mathrm{~N}_{42} \mathrm{O}_{33} \mathrm{~S}_{2}{ }^{2+}[\mathrm{M}+2 \mathrm{H}]^{2+} 1277.13$, found 1277.56. $\mathrm{C}_{100} \mathrm{H}_{172} \mathrm{~N}_{41} \mathrm{O}_{34} \mathrm{~S}_{2}{ }^{3+}[\mathrm{M}+3 \mathrm{H}]^{3+} 851.75$, found 852.28. $\mathrm{C}_{100} \mathrm{H}_{173} \mathrm{~N}_{41} \mathrm{O}_{34} \mathrm{~S}_{2}{ }^{4+}[\mathrm{M}+4 \mathrm{H}]^{4+}$ 639.06, found 640.20 .

CCP1 (3). CCP1 was synthesized following the procedures described in the general peptide synthesis. Next, this peptide was cyclized and purified as described in the general cyclization method. HPLC: rt. $12.753 \mathrm{~min}$. LC-MS (ESI+) $\mathrm{m} / z$ calcd for $\mathrm{C}_{100} \mathrm{H}_{171} \mathrm{~N}_{41} \mathrm{O}_{34} \mathrm{~S}_{2}{ }^{2+}[\mathrm{M}+2 \mathrm{H}]^{2+} 1277.61$, found 1278.08 . $\mathrm{C}_{100} \mathrm{H}_{172} \mathrm{~N}_{41} \mathrm{O}_{34} \mathrm{~S}_{2}{ }^{3+}[\mathrm{M}+3 \mathrm{H}]^{3+}$ 852.07, found 852.68. $\mathrm{C}_{100} \mathrm{H}_{173} \mathrm{~N}_{41} \mathrm{O}_{34} \mathrm{~S}_{2}{ }^{4+}[\mathrm{M}+4 \mathrm{H}]^{4+}$ 639.31, found 641.16.

CCP1(CNBz) (4). CCP1(CNBz) was synthesized following the procedures described in the general peptide synthesis. Next, this peptide was cyclized and purified as described in the general cyclization method. HPLC: rt. $14.854 \mathrm{~min}$. LC-MS (ESI+) $\mathrm{m} / z$ calcd for $\mathrm{C}_{108} \mathrm{H}_{176} \mathrm{~N}_{42} \mathrm{O}_{38} \mathrm{~S}_{2}{ }^{2+}[\mathrm{M}+2 \mathrm{H}]^{2+}$ 1367.12, found 1367.52. $\mathrm{C}_{108} \mathrm{H}_{177} \mathrm{~N}_{42} \mathrm{O}_{38} \mathrm{~S}_{2}{ }^{3+}[\mathrm{M}+3 \mathrm{H}]^{3+}$ 911.75, found 912.20. $\mathrm{C}_{108} \mathrm{H}_{178} \mathrm{~N}_{42} \mathrm{O}_{38} \mathrm{~S}_{2}{ }^{4+}[\mathrm{M}+4 \mathrm{H}]^{4+}$ 684.06, found 685.20.

CCP1(CNBz) Stability Measurements at Various $\mathrm{pH}$. The peptide was dissolved in $1 \% \mathrm{DMSO} / \mathrm{Mcllvaine}$ buffer $(\mathrm{pH} 4-$ 9 at a concentration of $0.2 \mathrm{mg} / \mathrm{mL}$ ). The reaction was set at 37 ${ }^{\circ} \mathrm{C}$ at $600 \mathrm{rpm}$ for 1-7 days. A sample was taken and was measured by LC-MS. The area under the curve of the chromatogram shows the percentage of starting material or degradation material (CCP1).

Cell Culture and Monoclonal Antibodies. Immortalized B cell clones recognizing CCP1 and tetanus toxoid (TT) were generated by transducing antigen-specific human memory $\mathrm{B}$ cells with retroviruses encoding $\mathrm{Bcl}-6$ and $\mathrm{Bcl}-\mathrm{xL}$, as previously described. $^{27,28}$ Cells were cultured in Dulbecco's modified Eagle's medium (DMEM) supplemented with $8 \%$ heatinactivated fetal calf serum, penicillin/streptomycin (PS, 100 $\mathrm{U} / \mathrm{mL}$ ), $2 \mathrm{mM}$ Glutamax, and $1 \mu \mathrm{g} / \mathrm{mL}$ puromycin in the presence of irradiated CD40L-expressing cells and mouse interleukin-21-Fc (mIL21-Fc). These B cell clones maintained the expression of membrane bound ACPA or anti-TT antibody and also secreted antibodies recognizing CCP1 or TT, respectively. Supernatants of the cell cultures that contained secreted monoclonal antibodies against CCP1 or TT were harvested after 3 days of culture.

RA Plasma. Peripheral blood was obtained from ACPApositive RA patients who visited the outpatient clinic of the Department of Rheumatology at Leiden University Medical Centre (LUMC). The patients met the 2010 ACR/EULAR criteria for RA at the time of diagnosis and gave written informed consent to participate in the study. Permission to conduct the study was obtained from the ethical review board 
A

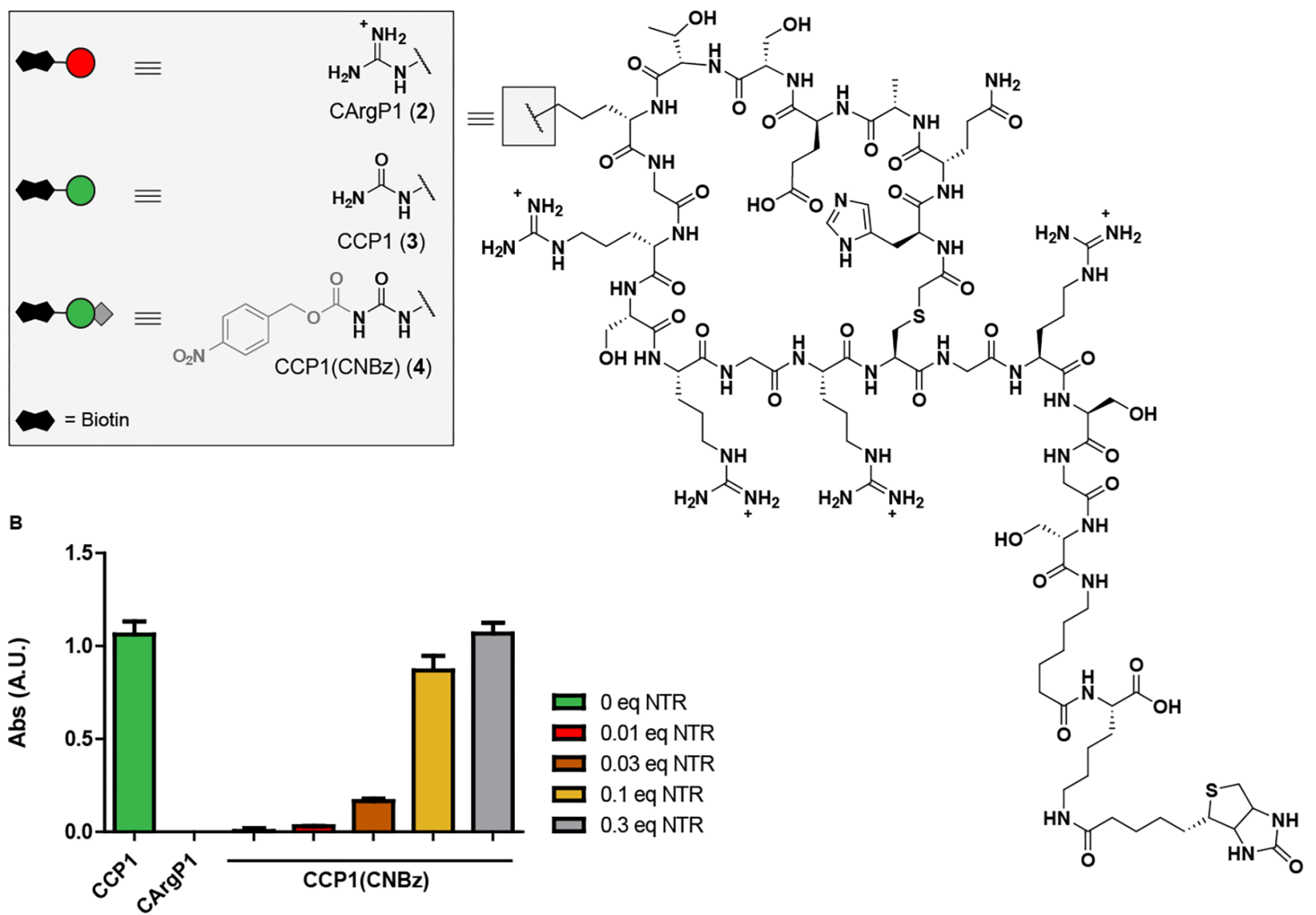

Figure 2. ACPA binding toward (blocked) CCP1 and antigen activation using NTR. (A) Structures of CArgP1 (2), CCP1 (3), and the CNBz protected CCP1 (4). Biotin is used for conjugation purposes; (B) CCP1 ELISA using protected antigens detected by monoclonal ACPA. One hour incubation of the protected peptide with different NTR concentrations fully restored ACPA binding. Abs: absorbance at $450 \mathrm{~nm}$. Experiment is performed twice in triplicate.

of LUMC. Blood plasma was obtained by centrifuging heparintreated peripheral blood.

ELISA Measurements. The ability of the $\mathrm{CNBz}$ moiety to protect CCP1 epitopes from the recognition of both monoclonal and polyclonal ACPA and the capacity of NTR to remove the $\mathrm{CNBz}$ group and recover $\mathrm{CCP} 1$ reactivity were assessed by ELISA. All reactants were dissolved in PBS $\mathrm{pH}=$ 7.4. Ten micromolar ( 1 equiv) biotinylated $\mathrm{CCP} 1(\mathrm{CNBz})$ was treated with $3 \mu \mathrm{M}$ ( 0.3 equiv), $1 \mu \mathrm{M}$ (0.1 equiv), $0.3 \mu \mathrm{M}(0.03$ equiv), and $0.1 \mu \mathrm{M}$ (0.01 equiv) NTR and 50 equiv NADH (both from Sigma-Aldrich) to test the NTR capacity for $1 \mathrm{~h}$ at $37^{\circ} \mathrm{C}$. Next, biotinylated CCP1, CArgP1, CCP1(CNBz), and NTR-pretreated CCP1 $(\mathrm{CNBz})$ were coupled to streptavidincoated ELISA plates (C96 Maxisorp Nunc-immuno plate, Thermo-Scientific). Undiluted supernatants of the immortalized B cell clones and 1:50 diluted patient's plasma samples were incubated with the respective antigens; antigen-bound IgG was detected by polyclonal rabbit antihuman IgG HRP (DAKO) and stained with ABTS. $\mathrm{H}_{2} \mathrm{O}_{2}$ (Sigma-Aldrich) or TMB-UP (Biomerieux). The absorbance of the colorimetric signal was measured with iMark TM Microplate Reader (BioRad) at 415 or $450 \mathrm{~nm}$, respectively.

FACS Measurements. Biotinylated CCP1 $(\mathrm{CNBz}), \mathrm{CCP} 1$, and CArgP1 were coupled with APC-labeled streptavidin (Lifetechnologies), as previously described. ${ }^{29}$ One equivalent of APC-labeled CCP1 $(\mathrm{CNBz})$ tetramer was treated with 0.3 equiv NTR and 50 equiv $\mathrm{NADH}$ for $1 \mathrm{~h}$ at $37^{\circ} \mathrm{C}$ in cell cultures containing either ACPA-expressing or TT-specific immortalized B cells in a 96-well plate. Subsequently, the cells were kept on ice for $30 \mathrm{~min}$, washed, resuspended with $1 \%$ paraformaldehyde, and measured by flow cytometry using BD LSRFortessa (BD Biosciences).

Cell Viability Assay. Biotinylated CCP1, CArgP1, and $\mathrm{CCP} 1(\mathrm{CNBz})$ were conjugated with streptavidin-saporin (Advanced Targeting systems) in a 4:1 ratio to make peptide-drug conjugates. The $1 \times 10^{4}$ ACPA-expressing or TT-specific B cell clones were cultured with medium, mIL21$\mathrm{Fc}$, and soluble CD40L (from Biolegend) in the presence of 0 , $0.1,1,10,100 \mathrm{nM}$ peptide-drug conjugates in a 96-well plate. After 4 days, supernatants were collected and XTT labeling and electron-coupling reagents (Roche) were added to the culture according to the manufacturer's protocol and incubated for $6 \mathrm{~h}$. Cell viability was measured on a iMark TM Microplate Reader (from BioRad).

\section{RESULTS AND DISCUSSION}

Synthesis of (Blocked) Citrullinated Antigens. We started our studies by exploring a synthetic strategy to generate a blocked cyclic citrullinated peptide (CCP) antigen. As the citrulline residue is key for recognition by ACPA and citrullinedirected BCRs, we envisioned that the ureido moiety of the citrulline residue itself would be the best position to introduce 


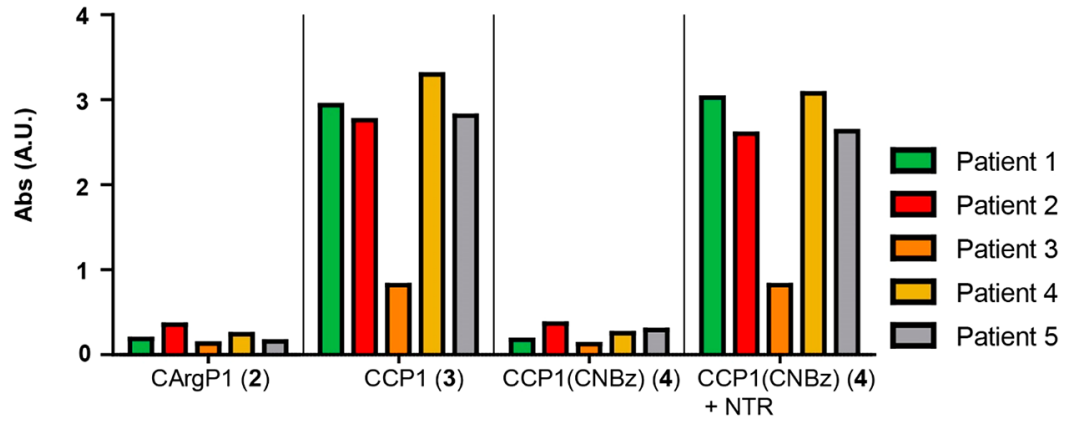

Figure 3. ELISA with the CXP1 antigens incubated with ACPA-positive patient sera. 0.3 equiv nitroreductase (NTR) was used for antigen activaion. Anti-Tetanus toxoid (TT) antibodies are used as negative control. Abs: absorbance at $415 \mathrm{~nm}$. This experiment was performed in duplicate.

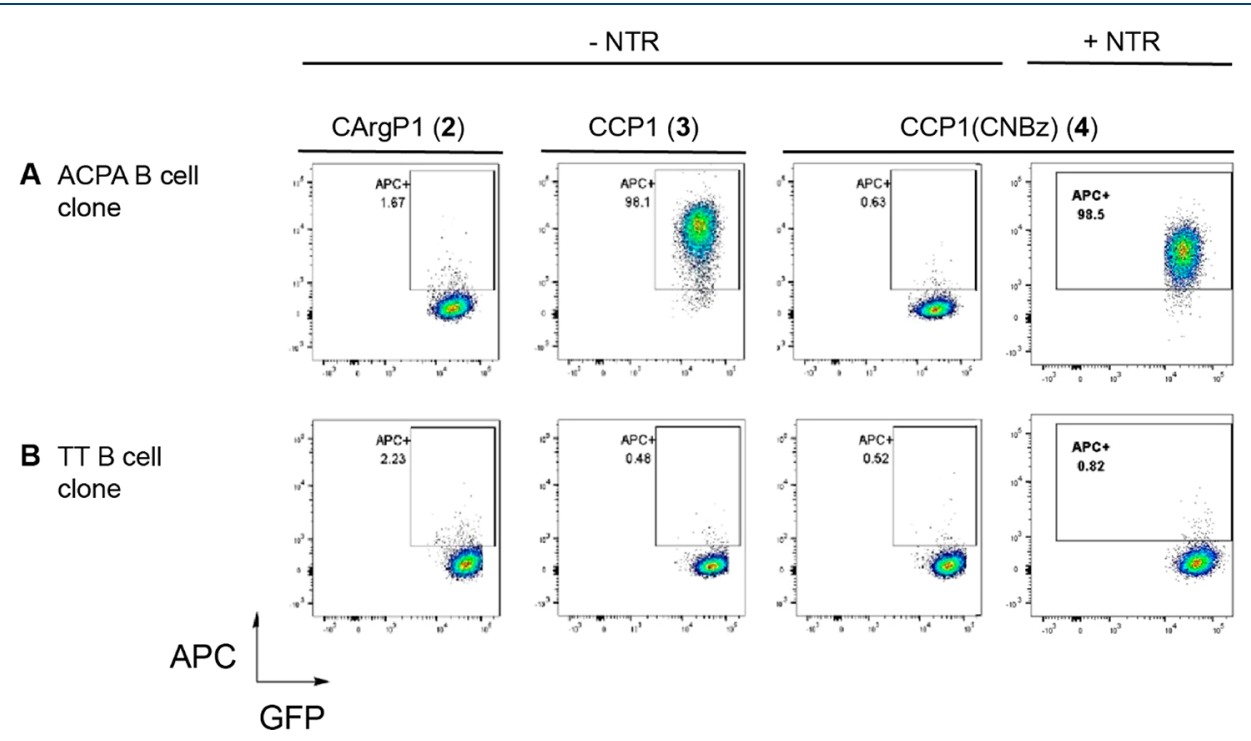

Figure 4. Flow cytometric binding studies of streptavidin-coupled, biotinylated CCP1, CArgP1, and (activated) CCP1(CNBz) to (A) ACPAexpressing B cell clone and (B) TT-specific B cell clone. This experiment was performed twice.

the blocking group. The required building block needed for solid phase peptide synthesis (SPPS) of the blocked CCP was obtained by reacting Fmoc-citrulline with para-nitrophenylchloroformate in THF in reasonable yield after recovery of the unreacted starting material (Supplementary Scheme S1). The carboxy-p-nitrobenzyl modified Fmoc-citrulline (1) proved very stable toward $20 \%$ piperidine and TFA and could thus be used in SPPS to produce the full CCP antigen.

We selected a cyclic citrullinated peptide 1 (CCP1) analogue, a well-known ACPA antigen, ${ }^{14,16}$ as initial antigen for our conjugate assembly (Figure 2). CCP1 is recognized by $37-62 \%$ of ACPA-positive sera, ${ }^{16}$ whereas the arginine containing variant of the peptide (CArgP1) does not have affinity for ACPA and can therefore serve as a negative control. CXP1 peptides (with $\mathrm{X}$ being different amino acids) were synthesized using standard Fmoc SPPS with arginine (2, $\mathrm{CArgP} 1)$ as the negative control, citrulline (3, CCP1) as the positive control and protected citrulline $1(4, \mathrm{CCP} 1(\mathrm{CNBz}))$ (Figure 2A). The CNBz-protected variant of CCP1 proved to be stable for at least 7 days in acidic to neutral $\mathrm{pH}$ (Supplementary Figure S1). A biotin moiety was installed at the single free amine functionality on resin for further experimental evaluation. The CXP1 peptides were covalently cyclized by first reacting the $\mathrm{N}$-terminus with chloroacetic anhydride followed by deprotection of the full peptide and substitution of the chloride by the internal cysteine.

NTR-Mediated Deprotection of CCP1(CNBz). Having the biotinylated controls and blocked CXP1 antigens 2-4 in hand, we explored the rate of $\mathrm{CNBz}$ removal by NTR. We first established that removal of the $\mathrm{CNBz}$ moiety from the citrulline building block 1 was fast and full removal was observed within 5 min using 0.3 equiv $\mathrm{NTR}$ and $\mathrm{NADH}$ as cofactor as evidenced by analytical HPLC analysis (Figure S2). Next, we evaluated whether the $\mathrm{CNBz}$ group blocked the CCP1 antigen from binding to ACPA in an enzyme-linked immunosorbent assay (ELISA) using monoclonal ACPA obtained from the supernatant of ACPA-producing immortalized B cells. These ACPA-expressing $\mathrm{B}$ cells were previously isolated from an ACPA-positive RA patient and transduced with BCL-XL, BCL6, and GFP genes resulting in ACPA-secreting and -expressing, GFP-positive immortalized B cells. ${ }^{30}$ Biotinylated and protected peptide 4 as well as control peptides 2 and 3 were coupled to a streptavidin-coated ELISA plate and incubated with monoclonal ACPA-containing supernatant. Removal of the $\mathrm{CNBz}$ group was performed before coupling of the peptide to the ELISA plate. Figure $2 \mathrm{~B}$ shows that monoclonal ACPA recognize $\mathrm{CCP} 1$, as expected. More importantly, the $\mathrm{CNBz}$ group on CCP1 blocked monoclonal ACPA-binding to the level observed for the negative control peptide (CArgP1 2). 
A

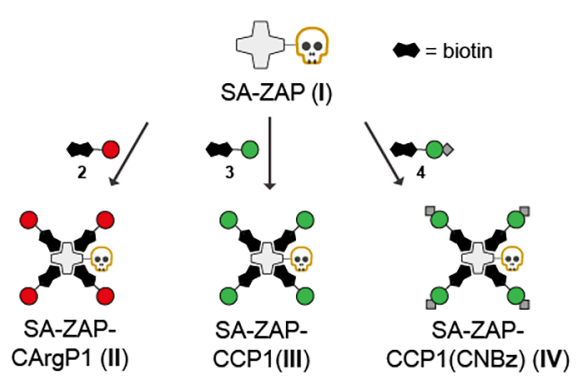

c

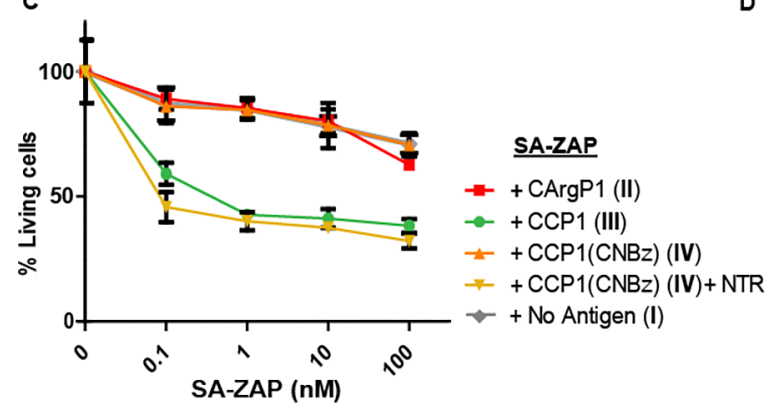

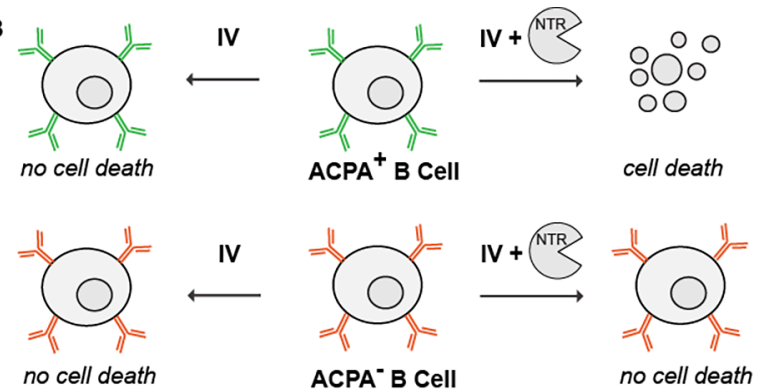

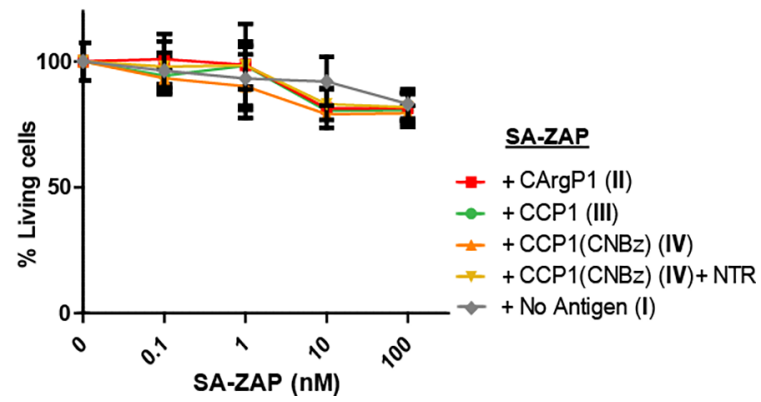

Figure 5. Selective cytotoxicity by enzymatic activation of CCP1-SA-ZAP conjugates. Schematic representation of streptavidin-ZAP bound to the CXP1 peptides (A) and the expected toxicity of the different SA-ZAP conjugates to ACPA expressing B cells (B). Percentage of living ACPAexpressing B cells (C) and TT-specific B cells (D) after 4 days of treatment with antigen-toxin conjugates.

Treatment of $\mathrm{CCP} 1(\mathrm{CNBz})$ with $\mathrm{NTR}$ and $\mathrm{NADH}$ as a cofactor for $1 \mathrm{~h}$ at $37{ }^{\circ} \mathrm{C}$ in $\mathrm{PBS} \mathrm{pH} 7.4$ showed a concentration-dependent antigen activation, as evidenced by restoration of the binding to the monoclonal ACPA. As observed previously, full restoration of the CCP1 antigen was already achieved within 5 min using 0.3 equiv NTR (Figure S3).

As ACPA present in blood of RA-patients are not monoclonal, ${ }^{31}$ we next investigated the recognition of these peptides by patient sera. We selected sera of five different patients that were highly positive for antibodies to CCP2, the common antigen used for the detection of ACPA in a clinical diagnostic setting. Four of these RA patients were highly positive and one weakly positive for CCP1 recognition (Figure 3 ). The CArgP1 negative control was not bound by patient ACPA, and, similarly, no recognition of $\mathrm{CCP} 1(\mathrm{CNBz})$ antigen was observed. Activation of the antigen using 0.3 equiv NTR resulted in the full recovery of initial binding toward the polyclonal ACPA for all five patients showing that both blocking and activation of CCP1 for recognition by patient derived polyclonal ACPA is feasible.

Antigen-Dependent Selective Cellular Targeting and Toxicity. Application of the sequential antigen prodrug targeting strategy presented here requires efficient antigen activation in the proximity of cells. To this end, biotinylated CXP1 antigens were conjugated to fluorescently labeled streptavidin tetramers to visualize antigen binding to $\mathrm{B}$ cells by flow cytometry. ${ }^{32}$ Two B cell clones derived from immortalized ACPA-expressing and tetanus toxoid (TT)specific primary B cells were used for this purpose. The antigen specificity of the immortalized B cell clones is shown in Figure S4.

Figure 4A shows staining of CCP1-streptavidin-APC conjugates ( $y$-axis) to clonal ACPA-expressing immortalized $\mathrm{B}$ cells (GFP-positive, $x$-axis), indicating binding of CCP1streptavidin tetramers to cell surface BCRs. No binding was observed for the CArgP1 and CCP1(CNBz) antigen variants, demonstrating specificity of the signals observed for CCP1. Notably, addition of 0.3 equiv NTR for $1 \mathrm{~h}$ almost completely recovered antigen-binding to ACPA-expressing B cells (last panel), while no binding was observed to TT-specific control B cell clones (Figure 4B). Together, these data indicate that blocking and activation of CCP1 can be achieved for antigenspecific recognition by both soluble antibodies and surfaceexpressed B cell receptors.

To demonstrate that restored antigen-recognition by $\mathrm{B}$ cells, could also result in selective killing of ACPA-expressing B cells, we conjugated the biotinylated antigen variants to a streptavidin-saporin conjugate (SA-ZAP, Figure 5A and B) ${ }^{33,34}$ Saporin is a cytotoxic ribosome inhibitor that induces cell death by apoptosis, ${ }^{35}$ which has been used in many in vivo studies as antibody-drug conjugate. ${ }^{36-40}$ Equal numbers $(1 \times$ $10^{4}$ ) of ACPA-expressing and TT-specific immortalized B cells were cultured with $0,0.1,1,10$, and $100 \mathrm{nM}$ antigen-SA-ZAP conjugates. After 4 days of incubation, a XTT cell viability assay was performed to assess the amount of remaining viable cells. The percentage of living cells was calculated by dividing the optical density value of cells treated with antigen-SA-ZAP by the optical density of cells treated in parallel with the corresponding antigen-SA complex. Figure $5 \mathrm{C}$ and D show the percentage of living ACPA-expressing B cells or TT-expressing $B$ cells, respectively, after treatment with SA-ZAP conjugated to CXP1 either treated or nontreated with NTR.

The exposure of cells to CCP1-SA-ZAP at $1 \mathrm{nM}$ as well as the activated $\mathrm{CCP} 1(\mathrm{CNBz})$ induced death of up to $60 \%$ of ACPA-expressing B cells. At this SA-ZAP concentration, 96\% of ACPA-expressing $B$ cells survived the treatment when bound to CCP1 $(\mathrm{CNBz})$, comparable to CArgP1-SA-ZAP or SA-ZAP without peptide. Increasing the concentration resulted in further increased cell death, although increasing cellular toxicity was then also noted for SA-ZAP that was not conjugated to any antigen (Figure 5C). The lack of $100 \%$ 
death of ACPA-expressing B cell clone by either CCP1-SAZAP or NTR-treated CCP1(CNBz)-SA-ZAP could relate to the transfection of these cells with antiapoptotic genes, which might make them less susceptible to toxic agents than would be for conventional B cells.

As the antigen-toxin conjugate, once it is activated by nitroreductase, can bind to both the B cell receptor of ACPAexpressing cells and to secreted ACPA molecules, we consider it important that deprotection eventually occurs in close vicinity to the $\mathrm{B}$ cell receptor that we envision to be achieved by an ADEPT approach. Nonetheless, binding of secreted ACPA molecules to the conjugate could lead to the formation of immune complexes. Circulating ACPA-immune complexes have been reported to be capable of stimulating effector cells in vitro via binding to $\mathrm{FC}_{\mathrm{C}}$ receptors. ${ }^{41}$ Thus, $\mathrm{Fc}_{\mathrm{c}}$ receptor-mediated effects such as antibody dependent cellular cytotoxicity cannot be fully excluded and future in vivo studies will have to be performed to evaluate this possibility.

Finally, the selectivity of the approach was demonstrated by the lack of toxicity of the conjugates for TT-specific B cells (Figure 5D), and also NTR by itself did not show toxic effects on the $\mathrm{B}$ cells used (Figure S5). These results indicate that CCP1-SA-ZAP and NTR-treated CCP1(CNBz)-SA-ZAP can be used for the selective depletion of ACPA-expressing $B$ cells ex vivo.

\section{CONCLUSIONS}

The high specificity of the ACPA immune response for RA, the therapeutic efficacy of CD20 depletion in the treatment of this disease, and the risks of long-lasting systemic immunosuppression associated with this treatment have fueled efforts aimed at the selective elimination of ACPA-expressing memory $B$ cells as a prospect of targeted therapy in RA. Here, we demonstrate a sequential two-step prodrug strategy to selectively eliminate autoreactive B cells. By exploiting the essential requirement of the citrulline residue in the antigen for recognition by ACPA-BCR and soluble ACPA molecules, we showed that blocking this amino acid with $\mathrm{CNBz}$ resulted in complete loss of binding toward ACPA and ACPA expressing $\mathrm{B}$ cells. Furthermore, the $\mathrm{CNBz}$ group could be removed by nitroreductase to restore binding of the antigen. Using this strategy, we selectively induced cell death in immortalized ACPA expressing B cell clones using an antigen coupled to a streptavidin-toxin, while TT-expressing B cells were insensitive to these conjugates.

We expect that removal of the blocking group in close proximity to the B cell membrane, for example, by using NTR, can circumvent binding of antigen to free circulating ACPA, thereby decreasing the risk for rapid clearance of the drug from tissue and the circulation. The CNBz removal using NTR may be beneficial as elevated levels of reductases are found in hypoxic inflamed tissue. ${ }^{42}$ In addition, NTR has been explored previously in $\mathrm{ADEPT}^{23}$ and enzyme-selective cofactors for $E$. coli NTR are reported circumventing the use of serum-sensitive cofactors such as $\mathrm{NAD}(\mathrm{P}) \mathrm{H}^{43}$

In conclusion, we show that we can selectively control the reconition of CCP1, thereby tuning the affinity toward ACPA and ACPA expressing B cells. Using this approach, we circumvent $\mathrm{CCP} 1(\mathrm{CNBz})$ from binding to ACPA and regain binding to the BCR after selective deprotection by NTR in the proximity of B cells, using a possible ADEPT construct. Since not all autoreactive B cells reside in inflamed tissue, but also in lymph nodes, we currently investigate additional approaches for the selective deprotection of target antigens including socalled 'click to release chemistry'. 44 In this study, we demonstrated the blocking and antigen activation in the context of the citrulline-specific B cell response, but we expect that this modular strategy will be applicable interchangeably for other (auto)antigens. The selectivity of the antigen and the possibility to block binding toward circulation ACPA brings us a step closer to the specific elimination of autoreactive B cells for the treatment of patients with ACPA-positive RA.

\section{ASSOCIATED CONTENT}

\section{S Supporting Information}

The Supporting Information is available free of charge on the ACS Publications website at DOI: 10.1021/acs.molpharmaceut.8b00741.

Characterization of 1-4, deprotection of Fmoc-Cit$(\mathrm{CNBz})$, deprotection over time, cell cytotoxicity of NTR (PDF)

\section{AUTHOR INFORMATION}

\section{Corresponding Author}

*E-mail: k.bonger@science.ru.nl.

ORCID

Kimberly M. Bonger: 0000-0001-9498-2620

Notes

The authors declare no competing financial interest.

\section{ACKNOWLEDGMENTS}

This research was funded by the NWO gravity program the 'Institute for Chemical Immunology'. K.M.B. acknowledges the Institute for Molecules and Materials of the Radboud University. H.U.S and R.E.M.T received support from the EU/EFPIA Innovative Medicines Initiative 2 Joint Undertaking (IMI2-JU) RTCure grant (contract no 777357). H.U.S is the recipient of a NWO-ZonMW VENI grant (project 91617107) and received support from the Dutch Arthritis Foundation (project 15-2-402).

\section{ABBREVIATIONS}

ACPA, anticitrullinated protein antibodies; ADEPT,antibodydirected enzyme prodrug strategy; $\mathrm{BCR}, \mathrm{B}$ cell receptor; CCP1,cyclic citrullinated peptide 1; CNBz,carboxynitrobenzyl; ELISA,enzyme-linked immunosorbent assay; FACS,fluorescence-activated cell sorting; HPLC,high performance liquid chromatography; NTR,nitroreductase; RA,rheumatoid arthritis; SA-ZAP,streptavidin-saporin; TT,tetanus toxoid; ZAP,saporin

\section{REFERENCES}

(1) Dörner, T.; Jacobi, A. M.; Lipsky, P. E. B cells in autoimmunity. Arthritis Research \& Therapy 2009, 11 (5), 247-247.

(2) Scott, D. L.; Wolfe, F.; Huizinga, T. W. J. Rheumatoid arthritis. Lancet 2010, 376 (9746), 1094-1108.

(3) Vossenaar, E. R.; van Venrooij, W. J. Citrullinated proteins: sparks that may ignite the fire in rheumatoid arthritis. Arthritis Research and Therapy 2004, 6 (3), 107-111.

(4) Valesini, G.; Gerardi, M. C.; Iannuccelli, C.; Pacucci, V. A.; Pendolino, M.; Shoenfeld, Y. Citrullination and autoimmunity. Autoimmun. Rev. 2015, 14 (6), 490-497.

(5) Jilani, A. A.; Mackworth-Young, C. G. The Role of Citrullinated Protein Antibodies in Predicting Erosive Disease in Rheumatoid 
Arthritis: A Systematic Literature Review and Meta-Analysis. Int. J. Rheumatol. 2015, 2015, 8.

(6) van Venrooij, W. J.; van Beers, J. J.; Pruijn, G. J. Anti-CCP antibodies: the past, the present and the future. Nat. Rev. Rheumatol. 2011, 7 (7), 391-398.

(7) Edwards, J. C.; Szczepanski, L.; Szechinski, J.; FilipowiczSosnowska, A.; Emery, P.; Close, D. R.; Stevens, R. M.; Shaw, T. Efficacy of B-cell-targeted therapy with rituximab in patients with rheumatoid arthritis. N. Engl. J. Med. 2004, 350 (25), 2572-81.

(8) Chatzidionysiou, K.; Lie, E.; Nasonov, E.; Lukina, G.; Hetland, M. L.; Tarp, U.; Gabay, C.; van Riel, P. L.; Nordstrom, D. C.; GomezReino, J.; Pavelka, K.; Tomsic, M.; Kvien, T. K.; van Vollenhoven, R. F. Highest clinical effectiveness of rituximab in autoantibody-positive patients with rheumatoid arthritis and in those for whom no more than one previous TNF antagonist has failed: pooled data from 10 European registries. Ann. Rheum. Dis. 2011, 70 (9), 1575-80.

(9) Kaplan, B.; Kopyltsova, Y.; Khokhar, A.; Lam, F.; Bonagura, V. Rituximab and Immune Deficiency: Case Series and Review of the Literature. Journal of Allergy and Clinical Immunology: In Practice 2014, 2 (5), 594-600.

(10) Reiners, K. S.; Hansen, H. P.; Krüssmann, A.; Schön, G.; Csernok, E.; Gross, W. L.; Engert, A.; von Strandmann, E. P. Selective killing of B-cell hybridomas targeting proteinase 3, Wegener's autoantigen. Immunology 2004, 112 (2), 228-236.

(11) Zocher, M.; Baeuerle, P. A.; Dreier, T.; Iglesias, A. Specific depletion of autoreactive $\mathrm{B}$ lymphocytes by a recombinant fusion protein in vitro and in vivo. Int. Immunol. 2003, 15 (7), 789-796.

(12) Nachreiner, T.; Kampmeier, F.; Thepen, T.; Fischer, R.; Barth, S.; Stöcker, M. Depletion of autoreactive B-lymphocytes by a recombinant myelin oligodendrocyte glycoprotein-based immunotoxin. J. Neuroimmunol. 2008, 195 (1-2), 28-35.

(13) Klose, D.; Saunders, U.; Barth, S.; Fischer, R.; Jacobi, A. M.; Nachreiner, T. Novel fusion proteins for the antigen-specific staining and elimination of $\mathrm{B}$ cell receptor-positive cell populations demonstrated by a tetanus toxoid fragment C (TTC) model antigen. BMC Biotechnol. 2016, 16 (1), 18.

(14) Schellekens, G. A.; Visser, H.; De Jong, B. A.; Van Den Hoogen, F. H.; Hazes, J. M.; Breedveld, F. C.; Van Venrooij, W. J. The diagnostic properties of rheumatoid arthritis antibodies recognizing a cyclic citrullinated peptide. Arthritis Rheum. 2000, 43 (1), 155-163.

(15) Trier, N. H.; Holm, B. E.; Slot, O.; Locht, H.; Lindegaard, H.; Svendsen, A.; Houen, G. Physical Characteristics of a Citrullinated Pro-Filaggrin Epitope Recognized by Anti-Citrullinated Protein Antibodies in Rheumatoid Arthritis Sera. PLoS One 2016, 11, 12.

(16) Schellekens, G. A.; de Jong, B. A. W.; van den Hoogen, F. H. J.; van de Putte, L. B. A.; van Venrooij, W. J. Citrulline is an essential constituent of antigenic determinants recognized by rheumatoid arthritis-specific autoantibodies. J. Clin. Invest. 1998, 101 (1), 273281.

(17) Prosser, G.; Copp, J.; Syddall, S.; Williams, E.; Smaill, J.; Wilson, W.; Patterson, A.; Ackerley, D. Discovery and evaluation of Escherichia coli nitroreductases that activate the anti-cancer prodrug CB1954. Biochem. Pharmacol. 2010, 79 (5), 678-687.

(18) Senter, P. D.; Saulnier, M. G.; Schreiber, G. J.; Hirschberg, D. L.; Brown, J. P.; Hellström, I.; Hellström, K. E. Anti-tumor effects of antibody-alkaline phosphatase conjugates in combination with etoposide phosphate. Proc. Natl. Acad. Sci. U. S. A. 1988, 85 (13), 4842.

(19) Walther, R.; Rautio, J.; Zelikin, A. N. Prodrugs in medicinal chemistry and enzyme prodrug therapies. Adv. Drug Delivery Rev. 2017, 118, 65-77.

(20) Sharma, S. K.; Bagshawe, K. D. Antibody Directed Enzyme Prodrug Therapy (ADEPT): Trials and tribulations. Adv. Drug Delivery Rev. 2017, 118, 2-7.

(21) Williams, E. M.; Little, R. F.; Mowday, A. M.; Rich, M. H.; Chan-Hyams, J. V. E.; Copp, J. N.; Smaill, J. B.; Patterson, A. V.; Ackerley, D. F. Nitroreductase gene-directed enzyme prodrug therapy: insights and advances toward clinical utility. Biochem. J. 2015, 471 (2), 131-153.

(22) Mauger, A. B.; Burke, P. J.; Somani, H. H.; Friedlos, F.; Knox, R. J. Self-immolative prodrugs: candidates for antibody-directed enzyme prodrug therapy in conjunction with a nitroreductase enzyme. J. Med. Chem. 1994, 37 (21), 3452-3458.

(23) Dubowchik, G. M.; Walker, M. A. Receptor-mediated and enzyme-dependent targeting of cytotoxic anticancer drugs. Pharmacol. Ther. 1999, 83 (2), 67-123.

(24) Jain, N.; Smith, S. W.; Ghone, S.; Tomczuk, B. Current ADC Linker Chemistry. Pharm. Res. 2015, 32 (11), 3526-3540.

(25) Hay, M. P.; Wilson, W. R.; Denny, W. A. A novel enediyne prodrug for antibody-directed enzyme prodrug therapy (ADEPT) using E. coli B nitroreductase. Bioorg. Med. Chem. Lett. 1995, 5 (23), 2829-2834.

(26) Xie, X.; Li, X.-M.; Qin, F.; Lin, J.; Zhang, G.; Zhao, J.; Bao, X.; Zhu, R.; Song, H.; Li, X. D.; et al. Genetically Encoded Photoaffinity Histone Marks. J. Am. Chem. Soc. 2017, 139 (19), 6522-6525.

(27) Kwakkenbos, M. J.; Diehl, S. A.; Yasuda, E.; Bakker, A. Q.; van Geelen, C. M.; Lukens, M. V.; van Bleek, G. M.; Widjojoatmodjo, M. N.; Bogers, W. M.; Mei, H.; Radbruch, A.; Scheeren, F. A.; Spits, H.; Beaumont, T. Generation of stable monoclonal antibody-producing B cell receptor-positive human memory $\mathrm{B}$ cells by genetic programming. Nat. Med. 2010, 16 (1), 123-8.

(28) Rivellese, F.; Mauro, D.; Nerviani, A.; Pagani, S.; FossatiJimack, L.; Messemaker, T.; Kurreeman, F. A. S.; Toes, R. E. M.; Ramming, A.; Rauber, S.; Schett, G.; Jones, G. W.; Jones, S. A.; Rossi, F. W.; de Paulis, A.; Marone, G.; El Shikh, M. E. M.; Humby, F.; Pitzalis, C. Mast cells in early rheumatoid arthritis associate with disease severity and support B cell autoantibody production. Ann. Rheum. Dis. 2018, 1.

(29) Kerkman, P. F.; Fabre, E.; van der Voort, E. I. H.; Zaldumbide, A.; Rombouts, Y.; Rispens, T.; Wolbink, G.; Hoeben, R. C.; Spits, H.; Baeten, D. L. P.; Huizinga, T. W. J.; Toes, R. E. M.; Scherer, H. U. Identification and characterisation of citrullinated antigen-specific $\mathrm{B}$ cells in peripheral blood of patients with rheumatoid arthritis. Ann. Rheum. Dis. 2016, 75 (6), 1170.

(30) Kwakkenbos, M. J.; van Helden, P. M.; Beaumont, T.; Spits, H. Stable long-term cultures of self-renewing B cells and their applications. Immunological reviews 2016, 270 (1), 65-77.

(31) Ioan-Facsinay, A.; el-Bannoudi, H.; Scherer, H. U.; van der Woude, D.; Ménard, H. A.; Lora, M.; Trouw, L. A.; Huizinga, T. W. J.; Toes, R. E. M. Anti-cyclic citrullinated peptide antibodies are a collection of anti-citrullinated protein antibodies and contain overlapping and non-overlapping reactivities. Ann. Rheum. Dis. 2011, 70 (1), 188.

(32) Kerkman, P. F.; Rombouts, Y.; van der Voort, E. I.; Trouw, L. A.; Huizinga, T. W.; Toes, R. E.; Scherer, H. U. Circulating plasmablasts/plasmacells as a source of anticitrullinated protein antibodies in patients with rheumatoid arthritis. Ann. Rheum. Dis. 2013, 72 (7), 1259-1263.

(33) Palchaudhuri, R.; Saez, B.; Hoggatt, J.; Schajnovitz, A.; Sykes, D. B.; Tate, T. A.; Czechowicz, A.; Kfoury, Y.; Ruchika, F. N. U.; Rossi, D. J.; Verdine, G. L.; Mansour, M. K.; Scadden, D. T. Nongenotoxic conditioning for hematopoietic stem cell transplantation using a hematopoietic-cell-specific internalizing immunotoxin. Nat. Biotechnol. 2016, 34, 738-745.

(34) Collins, B. E.; Blixt, O.; Han, S.; Duong, B.; Li, H.; Nathan, J. K.; Bovin, N.; Paulson, J. C. High-affinity ligand probes of CD22 overcome the threshold set by cis ligands to allow for binding, endocytosis, and killing of B cells. J. Immunol. 2006, 177 (5), 29943003.

(35) Bergamaschi, G.; Perfetti, V.; Tonon, L.; Novella, A.; Lucotti, C.; Danova, M.; Glennie, M. J.; Merlini, G.; Cazzola, M. Saporin, a ribosome-inactivating protein used to prepare immunotoxins, induces cell death via apoptosis. Br. J. Haematol. 1996, 93 (4), 789-94.

(36) Palchaudhuri, R.; Saez, B.; Hoggatt, J.; Schajnovitz, A.; Sykes, D. B.; Tate, T. A.; Czechowicz, A.; Kfoury, Y.; Ruchika, F. N. U.; Rossi, D. J.; Verdine, G. L.; Mansour, M. K.; Scadden, D. T. Non- 
genotoxic conditioning for hematopoietic stem cell transplantation using a hematopoietic-cell-specific internalizing immunotoxin. Nat. Biotechnol. 2016, 34, 738.

(37) Lee, S. C.; Seo, K. W.; Kim, H. J.; Kang, S. W.; Choi, H.-J.; Kim, A.; Kwon, B. S.; Cho, H. R.; Kwon, B. Depletion of Alloreactive T-Cells by Anti-CD137-Saporin Immunotoxin. Cell transplantation 2015, 24 (6), 1167-1181.

(38) Alonso, M. N.; Gregorio, J. G.; Davidson, M. G.; Gonzalez, J. C.; Engleman, E. G. Depletion of inflammatory dendritic cells with anti-CD209 conjugated to saporin toxin. Immunol. Res. 2014, 58 (23), 374-377.

(39) Kato, J.; Satake, N.; O’Donnell, R. T.; Abuhay, M.; Lewis, C.; Tuscano, J. M. Efficacy of a CD22-targeted antibody-saporin conjugate in a xenograft model of precursor-B cell acute lymphoblastic leukemia. Leuk. Res. 2013, 37 (1), 83-88.

(40) Kuroda, K.; Liu, H.; Kim, S.; Guo, M.; Navarro, V.; Bander, N. $\mathrm{H}$. Saporin toxin-conjugated monoclonal antibody targeting prostatespecific membrane antigen has potent anticancer activity. Prostate 2010, 70 (12), 1286-1294.

(41) England, B. R.; Thiele, G. M.; Mikuls, T. R. Anticitrullinated protein antibodies: origin and role in the pathogenesis of rheumatoid arthritis. Curr. Opin. Rheumatol. 2017, 29 (1), 57-64.

(42) Quiñonez-Flores, C. M.; González-Chávez, S. A.; PachecoTena, C. Hypoxia and its implications in rheumatoid arthritis. J. Biomed. Sci. 2016, 23 (1), 62-70.

(43) Friedlos, F.; Knox, R. J. Metabolism of nad(p)h by blood components: Relevance to bioreductively activated prodrugs in a targeted enzyme therapy system. Biochem. Pharmacol. 1992, 44 (4), 631-635.

(44) Versteegen, R. M.; Rossin, R.; ten Hoeve, W.; Janssen, H. M.; Robillard, M. S. Click to Release: Instantaneous Doxorubicin Elimination upon Tetrazine Ligation. Angew. Chem., Int. Ed. 2013, 52 (52), 14112-14116. 